\title{
A Feasibility Study on a Micro Hydro Power Plant at Coban Jahe Waterfall, Jabung, Malang Regency
}

Sudarman ${ }^{\mathrm{a}}$, Wahyu Guszolil ${ }^{\mathrm{b}}$, Daryono ${ }^{\mathrm{c}}$, Muhammad Lukman ${ }^{\mathrm{d}}$

a,b,c,d Mechanical Engineering Dept, Engineering Faculty, University of Muhammadiyah Malang Jl.Raya Tlogomas No.246., Malang 65144

Telp.(0341)4624318 - 128 Fax. (0341) 460782 e-mail: sudarman@umm.ac.id

\begin{abstract}
Micro Hydro Power (MHP) Plant is a small-scale power plant under $100 \mathrm{~kW}$. Generally, MHP is built in a place that the electricity network has not touched. Many waterfalls in Taji Village are only used as tourist attractions. One of them is Coban Jahe waterfall which has a water discharge of $0.60567 \mathrm{~m} 3 / \mathrm{s}$ in the dry season. Waterfall in Coban Jahe was used and planned as Micro Hydro Power Plant, it was called as MHP. Potential electric power generated from the MHP Coban Jahe Waterfall is $14.0368 \mathrm{~kW}$ with an effective head of $3.4742 \mathrm{~m}$. The results show from the financial analysis, the construction of MHP is quite feasible with NPV of Rp. 45,676,769, BCR of 1.0852, which means it is feasible to be continued, the Payback Period is 9 years which does not exceed the project life, and the IRR obtained is $10,0087 \%$ which the projects are feasible and profitable to build.
\end{abstract}

Keywords: MHP; coban jahe; discharge; head; power; npv; bcr; payback period; irr

\section{INTRODUCTION}

Water as a basic necessity of life is an important component for the quality of human life [1,2]. As an agricultural country, Indonesia has a fairly large water consumption power in the agricultural sector, especially in terms of irrigation [3]. In fact, Indonesia has a geographical location where some areas are hills and mountains [4,5], which sometimes become an obstacle in fulfilling the daily water supply. In comparison, the demand for electricity and fresh water is increasing due to the increase in population and comfort level of human beings. Micro hydropower is one of the best available solutions as it has economic, social, and environmental benefits and has a huge potential globally $[6,7]$. So this will make the demand for micro-hydro power generation [8].

From the background above, the construction of a Micro Hydro Power (MHP) Plant is one of the alternative energies that can be applied in Taji Village, Jabung District, Malang Regency, where there are many springs. The definition of micro-hydro or Microhydro Power Plant is a small-scale power plant that uses hydropower $[9,10]$ as its driving force such as irrigation channels, rivers, or natural waterfalls by utilizing the waterfall height (head) and the amount of water discharge [11-13]. Micro-hydro-electric power is both an efficient and reliable form of a clean source of renewable energy. It can be an excellent method of harnessing renewable energy from small rivers and streams [14]. From the explanation above, it is necessary to have a deeper analysis both from technical analysis and financial analysis.

\section{Methods}

In conducting research, especially for technical and financial data collection, it is necessary to have a good and correct methodology because good methodology 
produces good results. This Micro-hydro Power Plant Feasibility Study is made based on the flow chart as follows below in Figure 1:

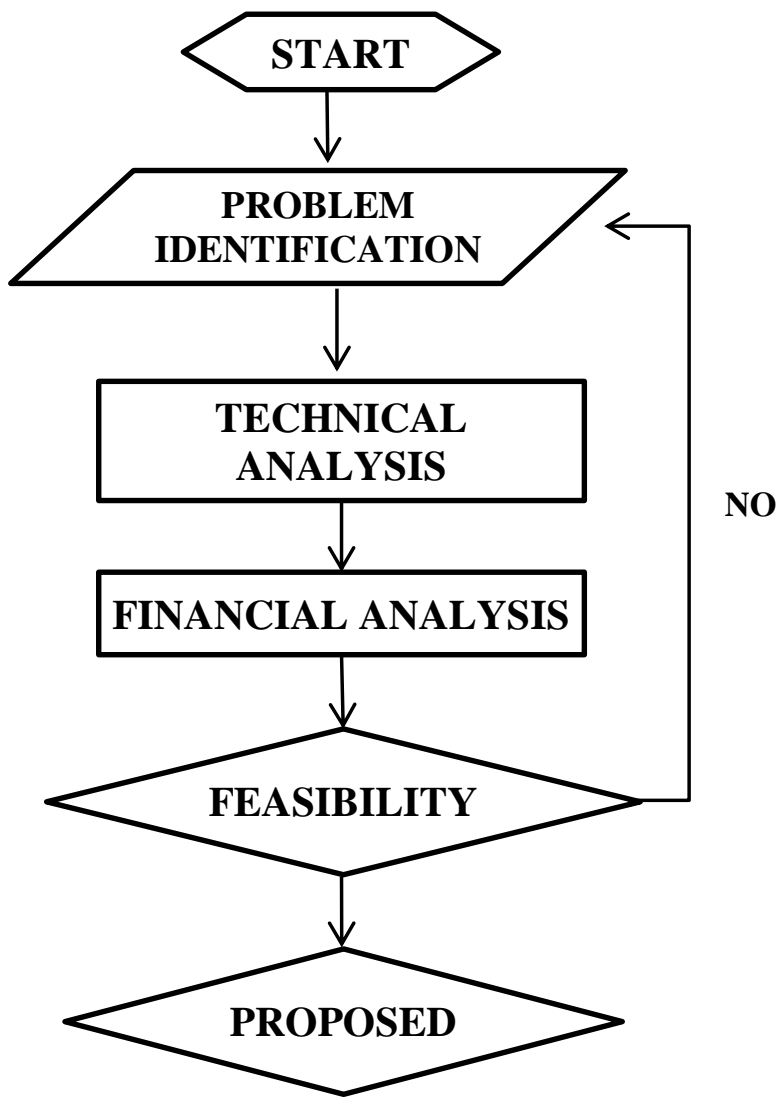

Figure 1. Feasibility Study Flowchart

\section{Result ANd Discussion}

\subsection{Water Discharge}

The first step in carrying out technical analysis is by taking the discharge data from the Coban Jahe waterfall flow. This process requires a minimum of 3 people to take the water discharge. By counting the cross-Section Area (m2), Velocity of flow $(\mathrm{m} / \mathrm{s})$ and Water Discharge (m3/s). Then obtained the water discharge as follows in Table 1:

Table 1. The average Water Discharge

\begin{tabular}{cccc}
\hline Location & Cross section area $\left(\mathbf{m}^{2}\right)$ & Velocity of Flow $(\mathbf{m} / \mathbf{s})$ & Water discharge $\left(\mathbf{m}^{3} / \mathbf{s}\right)$ \\
\hline 0 & 0 & 0 & 0 \\
1 & 0,483 & 0,2908 & 0,1404 \\
2 & 0,657 & 1,092 & 0,8666 \\
3 & 0,441 & 0,1679 & 0,0865 \\
& Velocity of Flow mean & & $0,5169 \mathrm{~m} / \mathrm{s}$ \\
& Water discharge mean & $0,9318 \mathrm{~m} / \mathrm{s}^{3}$ \\
\hline
\end{tabular}

The calculation is carried out through the following equation [3].

$$
\begin{aligned}
& Q=\left(A_{1} \times V_{1}\right)+\left(A_{2} \times V_{2}\right)+\left(A_{3} \times V_{3}\right) \\
& Q=(0,483 \times 0,2908)+(0,657 \times 1,092)+(0,441 \times 1,679) \\
& Q=0,1404+0,7174+0,0740
\end{aligned}
$$




$$
\begin{aligned}
& Q=0,9318 \mathrm{~m}^{3} / \mathrm{s} \\
& Q=c Q_{\text {total }}
\end{aligned}
$$

With

$c \quad=$ The water depth with free-flow, so the correction factor is 0.65 ,

$\mathrm{Q}_{\mathrm{d}}=$ Total water discharge $\left(\mathrm{m}^{3} / \mathrm{s}\right)$

$Q_{d}=0,65 \times 0,9318=0,60567 \frac{\mathrm{m}^{3}}{\mathrm{~s}}$

\subsection{Weir and intake}

This weir is located at an elevation point of $690 \mathrm{~m}$ with a coordinate point of $7^{\circ}$ $58^{\prime} 10^{\prime \prime} \mathrm{S} 112^{\circ} 48^{\prime} 10^{\prime \prime} \mathrm{E}$. The dam is planned to be 12 meters long, 3 meters high, and 9.2 meters wide, equipped with a spillway channel with a width of $5 \mathrm{~m}$, a height of $2 \mathrm{~m}$, and a length of $2 \mathrm{~m}$, as shown in Figure 2. The dimension of intake is planned to be $0.8 \mathrm{~m}$ length, $0.4 \mathrm{~m}$ width, and $0.25 \mathrm{~m}$ distance from the free surface. The weir is planned to use a single side gate that is less than $2.5 \mathrm{~m}$ in width. And the design of gate with sliding gate. The retrieval capacity must be at least $120 \%$ of the dimension requirement to increase flexibility and to be able to meet higher needs over the life of the project.

$Q_{\text {in }}=1,2 Q_{d}$
$Q_{\text {in }}=1,2 \times 0,60567=0,7268 \frac{\mathrm{m}^{\mathrm{s}}}{\mathrm{s}}$

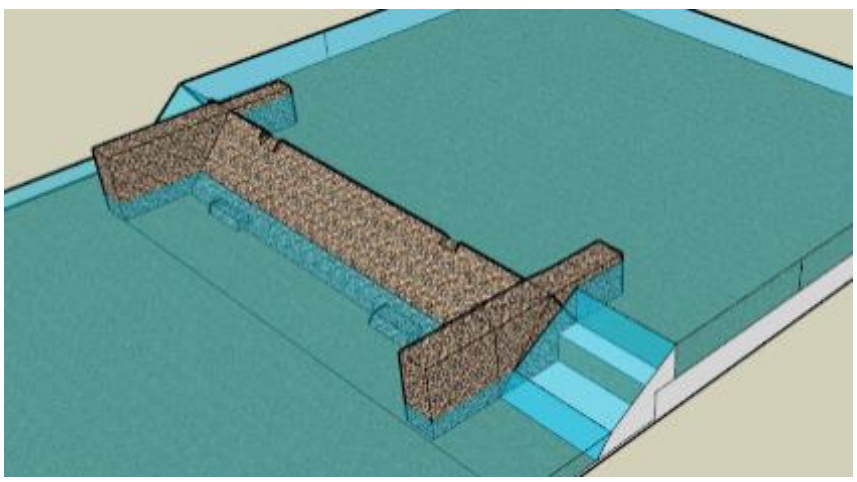

Figure 2. The design of Dam/weir

\subsection{Headrace}

In this study, the headrace with the trapezoidal open channel and length of approximately 50 meters width of $90 \mathrm{~cm}$ having a height of $75 \mathrm{~cm}$ and a channel base width of $70 \mathrm{~cm}$, as shown in Figure 3 . However, the water carrying channel must be able to hold water more than $10 \%$ higher in operation, the forebay water level does not drop from its usual height, and for guard height to avoid overtopping in case of excess discharge. The formula for the trapezoid-shaped channel is as follows [15].

$$
\begin{aligned}
Q & =V \cdot A \\
V & =\frac{1}{n} \times R^{\frac{2}{3}} \times S^{\frac{1}{2}} \\
R & =\frac{A}{P}
\end{aligned}
$$

With:

$\mathrm{Q}=$ Water Discharge $\left(\mathrm{m}^{3} / \mathrm{s}\right)$

$\mathrm{V}=$ Velocity of Flow rate $(\mathrm{m} / \mathrm{s})$

$\mathrm{R}=$ hydraulic spokes $(\mathrm{m})$

$A=$ Cross section area $\left(m^{2}\right)$

$\mathrm{P}=$ Wet of circumference $(\mathrm{m})$

$\mathrm{s}=$ slope of the channel base 
$\mathrm{n}=$ coefficient of roughness (for slice 0.0017 )

$\mathrm{h}=$ water level $(\mathrm{m})$,

$\mathrm{b}=$ wide bottom channel $(\mathrm{m})$

Table 2. Manning on the headrace

\begin{tabular}{llc}
\hline Tunnel & Explanation & 'n Manning \\
\hline Land & straight, new, uniform, ramps and clean & $0,016-0,033$ \\
& Winding, sloping and grassy & $0,023-0,040$ \\
& Poorly maintained and dirty & $0,050-0,140$ \\
& The ground is rocky, rough and irregular & $0,035-0,045$ \\
Pair & Gravelly & $0,023-0,035$ \\
& A pair of split stones & $0,017-0,030$ \\
Concrete & Smooth, good connection and flat & $0,014-0018$ \\
& Less smooth and connection is not flat & $0,018-0,030$ \\
\hline
\end{tabular}

$A=(B \times m . h) h=(0,70 \times 0,75 \times 0,5) 0,5=0,13125 \mathrm{~m}^{2}$

$P=B+2 h\left(m^{2}+1\right)^{0,5} 0,70+2 \times 0,5\left(0,75^{2}+1\right)^{0,5}=1,9 m$

$R=\frac{0,13125 \mathrm{~m}^{2}}{1,9 \mathrm{~m}}=0,06907 \mathrm{~m}$

Then,

$S=\sqrt{\frac{n}{R^{2 / 3}}}=\sqrt{\frac{0,0017}{0,06907^{2 / 3}}}=0,0647$

Then it can be obtained $\quad W=\sqrt{0,5 \times 0,5}=0,50$
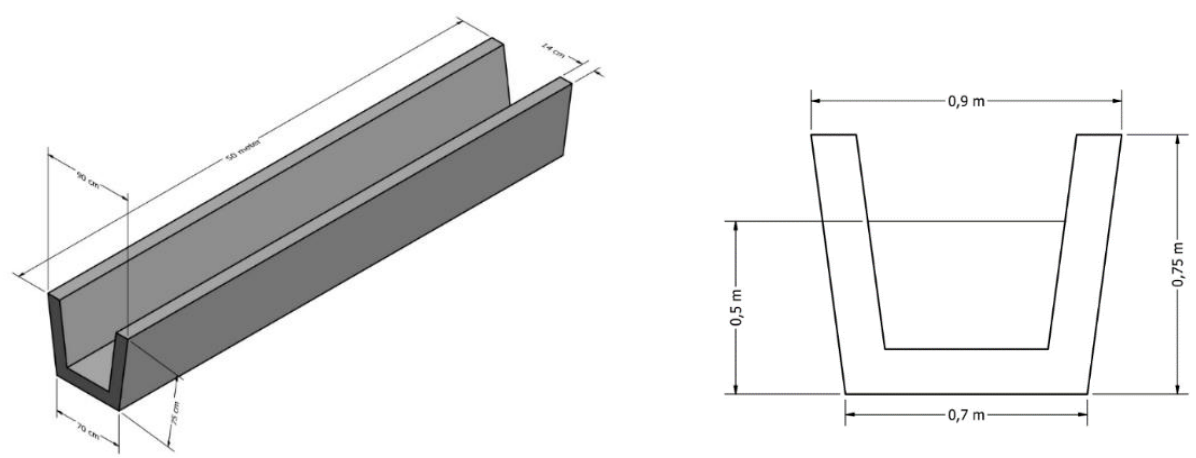

Figure 3. Design of the headrace

\subsection{Forebay}

A calming tub or forebay is located before the approach pipeline, which has a steep slope and hits the turbine's blades. The design of this calming basin will be provided with complementary buildings such as overflow, sediment drainage facilities, filters, openclose (stop-log) gates, as shown in Figure 4. The formula for the heating bath size is as follows: [15]

Calming tube/forebay area, $A=B L$

Penstock cross-section area: $A=\frac{\pi}{4} D^{2}$

The velocity of flow at intake: $V=\frac{4}{A}$

Water depth above penstock: $s=0,54 x V x D^{0,5}$

The depth of the water in the soaking tub: $T=s+D+f$

The volume of the tranquilizer pool $\mathrm{V}=\mathrm{AT}$

The width of the forebay, $B=3 B=3 \times 0.5 \mathrm{~m}=1.5 \mathrm{~m}$

The length of the forebay, $L=2 B=2 \times 1.5 \mathrm{~m}=3 \mathrm{~m}$ 
The area of the forebay, $A=B L=1,5 \times 3=4,5 \mathrm{~m}^{2}$

The cross-sectional area of the penstock, $A=\frac{\pi}{4} D^{2}=0,785 \times 0,5938^{2}=0,2767 \mathrm{~m}^{2}$

The flow velocity when entering the pipe, $V=\frac{Q}{A}=\frac{0,5938}{0,2767}=2,146 \frac{\mathrm{m}}{\mathrm{s}}$

The water depth above the penstock $s=0,54 V D^{0,5}=0,54 \times 2,146 \times 0,5938^{0,5}=$ $0,8929 m$

The depth of the water as a tranquilizer pool

$$
T=s+D+f=0,8929+0,5938+0,1=1,5867 m
$$

The volume of the water as a tranquilizer pool $V=A T=4,5 \times 1,5867=7,1401 \mathrm{~m}^{3} \cong$ $7,2 \mathrm{~m}^{3}$

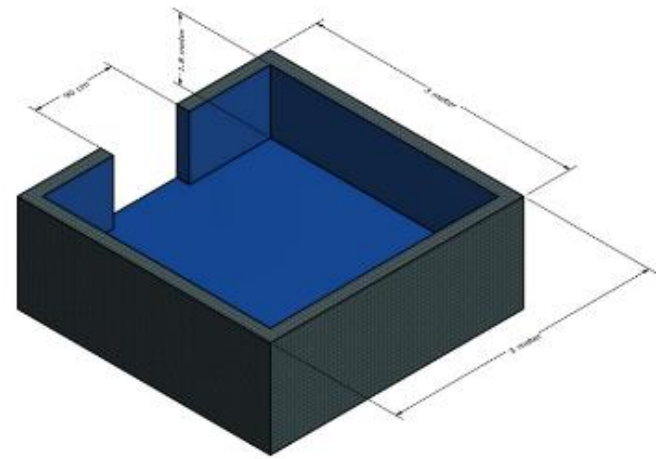

Figure 4. The design of Forebay

\subsection{Penstock}

Penstock is planned using cold-rolled steel and to be joined by welds and flanges as joints. The penstock diameter can be rapidly calculated to ensure that the pipe is rapidly durable, safe, economical, and practical. The following equation can be used:

$$
D=2,69 x\left(\frac{n^{2} x Q^{2} x L}{H}\right)^{0,1879} \text { (Rizal Firmansyah, et. al, 2014) }
$$

With:

$\mathrm{D}$ = penstock diameter $(\mathrm{m})$

$\mathrm{n}=$ penstock coefficient (for welded steel 0,012)

$Q=$ water discharge $\left(0,60567 \mathrm{~m} / \mathrm{s}^{3}\right)$

$\mathrm{L}=$ penstock length $(20 \mathrm{~m})$

$\mathrm{H}=$ Head gross $(4 \mathrm{~m})$, then:

$$
\begin{aligned}
& D=2,69 \times\left(\frac{0,012^{2} \times 0,60567^{2} \times 24}{4}\right) 0,1875 \\
& D=2,69 \times\left(\frac{0,012^{2} \times 0.60567^{2} \times 24}{4}\right) 0,1875 \\
& D=0,5938 \cong 0,6 \text { meter }
\end{aligned}
$$

\begin{tabular}{|c|c|c|c|c|}
\hline Material & $\begin{array}{c}\text { Young Modulus } \\
\text { of elasticity } \\
E\left(N / m^{3}\right) E 9\end{array}$ & $\begin{array}{l}\text { Coefficient of linear } \\
\text { expansion a (m/m } \\
\left.{ }^{\circ} \mathrm{c}\right) \mathrm{E} 6\end{array}$ & $\begin{array}{l}\text { Ultimate tensile } \\
\text { strength }\left(\mathrm{N} / \mathrm{m}^{2}\right) \\
\mathrm{E} 6\end{array}$ & $\mathbf{n}$ \\
\hline Welded Steel & 206 & 12 & 400 & 0,012 \\
\hline Polyethylene & 0,55 & 140 & 5 & 0,009 \\
\hline $\begin{array}{l}\text { Polyvinyl Chloride } \\
\text { (PVC) }\end{array}$ & 2,75 & 54 & 13 & 0,009 \\
\hline Asbestos Cement & n.a & 8,1 & n.a & 0,011 \\
\hline Cast Iron & 78,5 & 1 & 140 & 0,014 \\
\hline Ductile Iron & 16,7 & 11 & 340 & 0,015 \\
\hline
\end{tabular}

Table 3. Materials Used in penstock 


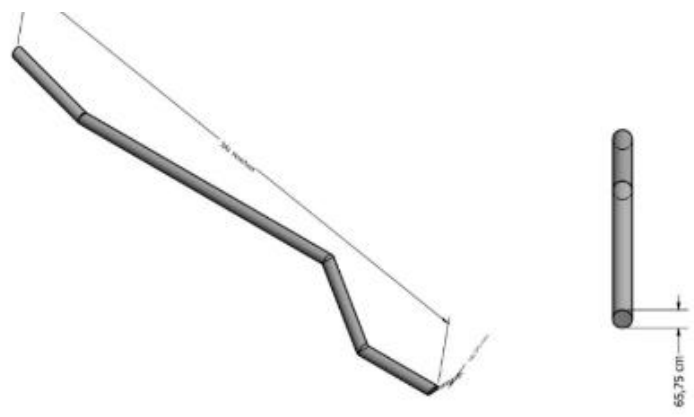

Figure 5. Penstock

The velocity of flow at the penstock

The velocity of flow by the following equation:

$V=0,125 \sqrt{2 g h}$

With

$\mathrm{V}=$ velocity of flow in the penstock,

$\mathrm{g}=$ acceleration due to gravity of $9.81 \mathrm{~m} / \mathrm{s}^{3}$,

$\mathrm{h}=$ gross head, then:

$$
\mathrm{V}=0,125 \mathrm{~V}=0,125 \sqrt{2 \times 9,81 \frac{\mathrm{m}}{\mathrm{s}^{3}} \times 4 \mathrm{~m}}=1,1073 \frac{\mathrm{m}}{\mathrm{s}}
$$

\section{Penstock Thickness}

The design of the pipe thickness $\delta(\mathrm{mm})$, by the following equation:

$$
\partial=D^{3} \sqrt{\frac{n p_{o}}{2 E}}
$$

Where $\mathrm{Po}=0.1 \mathrm{Mpa}$, and $\mathrm{E}=200 \mathrm{Gpa}$, then:

$$
\partial=0,6093^{3} \sqrt{\frac{4 \times 0,1}{2 \times 200}}=0,06093 \mathrm{~m} \cong 6 \mathrm{~mm}
$$

(The penstock thickness is quiet secure, according to guidelines with a minimum of 1.5 $\mathrm{mm})$

\subsection{Power House}

The design planning for the powerhouse itself uses the SketchUp application as support. The dimensions of the powerhouse itself are 7 meters long, 5 meters wide, 5 meters high.

\subsection{Net Head}

Net head is the difference between gross head and head loss in the pipe. Gross head is the vertical distance between the source water surface and the level of the tailrace for the reaction turbine and the nozzle exit for the impulse turbine. The head loss in the pipe system is in the form of head loss in the pipe and head loss for piping equipment such as connections, valves, branching, and diffusers and so on. Head losses major are calculated using the following calculation formula [16].

$$
h f=f x \frac{\mathrm{LV}^{2}}{\mathrm{D} .2 \mathrm{~g}}
$$

With 
$\mathrm{V}=$ velocity of flow in the pipe $(1.1073 \mathrm{~m} / \mathrm{s})$

$f=$ friction efficiency $=0.065$ (from moody diagram)

$\mathrm{g}=$ acceleration of gravity $9.8 \mathrm{~m} / \mathrm{s} 2$

$\mathrm{L}=$ pipe length (24 meters)

$\mathrm{D}=$ inside diameter of pipe $(0.5938 \mathrm{~m})$

Then it found,

$$
h f=0,065 \times \frac{24 \text { meter } \times 1,1073 \mathrm{~m} / \mathrm{s}}{0,5938 \times 2 \times 9,8 \mathrm{~m} / \mathrm{s}^{2}}=0,1484 \mathrm{~m}
$$

Losses on joining, hs:

$h s=k \frac{v^{2}}{2 \cdot g}$

Where $\mathrm{k}=$ coefficient 0,2 for an open valve

$$
h s=0,2 \times \frac{1,107^{2} \mathrm{~m} / \mathrm{s}}{2.9,8 \mathrm{~m} / \mathrm{s}^{2}}=0,0124
$$

Losses in the trash filter (Trashrack loss) $\Delta \mathrm{Hr}_{\mathrm{r}}$

$$
\Delta H_{r}=\varphi\left(\frac{s}{b}\right)^{\frac{4}{3}} \frac{v^{2}}{2 g} \sin \alpha \quad[15]
$$

Coefficient based on the shape of the mesh bar profile, form factor $(2.4$ for rectangles, and 1.8 for round bars), $\mathrm{s}=$ thickness of the mesh bars $(\mathrm{m}), \mathrm{b}=$ distance between bars $(\mathrm{m}), \alpha=$ slope against horizontal $\left(75^{\circ}\right)$,

$$
\Delta H_{r}=2,4 \times\left(\frac{0,01}{0,015}\right)^{\frac{4}{3}} \times \frac{1,107^{2} \frac{m}{s}}{2 \times 9,8 \frac{m}{s^{2}}} \times \sin 75^{\circ}=0,303 \mathrm{~m}
$$

\subsection{Water Turbine}

In general, the research results in the field show the potential for developing PLTMH with a head height of $6-60 \mathrm{~m}$, which can be categorized as the low and medium head. The graphic in Figure 5 below can help with turbine selection.

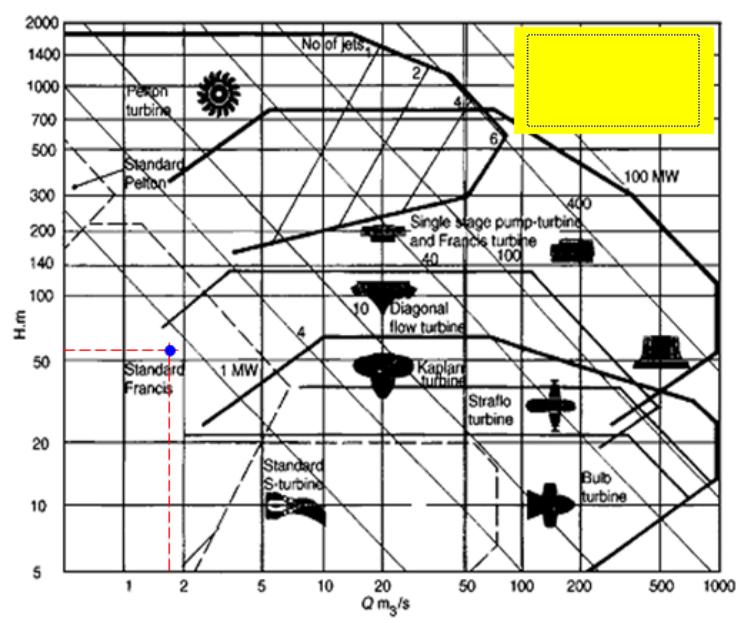

Figure 5. Turbine Selection

In determining the type of turbine, first determine the specific speed using the following Kaplan Turbine speed equation:

$$
N=\frac{2283}{H^{0,486}}
$$


The speed of water entering the turbine impeller is $V=c \sqrt{2 g h}$

Where $\mathrm{c}=$ velocity coefficient $(0,95 \leq \mathrm{C} \leq 0,98)$, maka

$$
V=0,96 \sqrt{2 \times 9,81 \frac{m}{s^{2}} \times 3,4742 m}=7,9258 \mathrm{~m} / \mathrm{s}
$$

Spesifik Turbine speed $N_{S}=\frac{2283}{3,4742^{0.486}}=1246,38$

Then it can be calculated the turbine speed $\mathrm{N}_{\mathrm{t}}(\mathrm{rpm})$ with the following equation,

$$
\begin{aligned}
& N_{t}=\frac{N_{s} H^{5 / 4}}{\sqrt{P}} \\
& N_{t}=\frac{1246,38 \times 3,4742^{5 / 4}}{\sqrt{16,5139}}=1454,76943 \mathrm{rpm} \cong 1455 \mathrm{rpm}
\end{aligned}
$$

\subsection{Power}

Net fall height is 3.4742 and discharge is $0.60567 \mathrm{m3} / \mathrm{s}$, turbine efficiency $\eta t=0.80$, generator efficiency $n g=0.85$, then the electric power generated:

$$
\begin{aligned}
& P=\eta_{t} \times g \times Q \times H_{e f f} \\
& \text { Water power } P=0,8 \times 9,81 \times 0,60567 \times 3,4742=16,5139 \mathrm{~kW}
\end{aligned}
$$

Generator power $P_{g}=P \times \eta_{g}=16,5139 \times 0,85=14,0368 \mathrm{~kW}$

Based on the above analysis, it shows that the mean flow rate of Coban Jahe Waterfall is $0.60567 \mathrm{~m} 3 / \mathrm{s}$ with an effective flow rate of $3.4742 \mathrm{~m}$ and is estimated to produce electric power of $14.0368 \mathrm{~kW}$.

\subsection{Financial Analysis}

The economic analysis was carried out to evaluate the feasibility of building an MHP in Coban Jahe to determine the amount of financial benefits that were given. With energy sales costs of Rp. 1,100 per kWh with PLN sales benchmarks, and in this study, it is assumed that the project life is 10 years and taking into account the PF power factor of $70 \%$, the income that will be obtained in one year is:

$$
\begin{aligned}
& \frac{\text { Energy }}{\text { Year }}=P_{\text {net }} \times 8760 \times P F \\
& \frac{\text { Energy }}{\text { Year }}=14,0368 \times 8760 \times 70 \%=86073,6576 \mathrm{kWh} \\
& \text { Revenue }=(\text { Rp. } 1100 / \mathrm{kWh}) \times 86073,6576 \mathrm{kWh}=R p .94 .681 .023,-
\end{aligned}
$$

Table 4. Investment Costs Issued

\begin{tabular}{llr}
\hline No & Descriptions & Total (Rp) \\
\hline 1 & Preparation works & 14.002 .188 \\
2 & Building works & - \\
& a $\quad$ Weir / Intake & 52.176 .415 \\
& b $\quad$ Forebay & 21.936 .632 \\
& C $\quad$ Spillway & 1.340 .313 \\
& d $\quad$ Headrace & 13.403 .128 \\
& e Penstock $\quad$ PowerHouse & 111.746 .103 \\
& f $\quad$ 52.408.438 \\
3 & Electrical-Mechanical Works & 192.091 .600 \\
4 & Tax 10\% & 45.910 .482 \\
& Total & $\mathbf{5 0 5 . 0 1 5 . 2 9 8}$ \\
\hline
\end{tabular}

The construction of MHP Coban Jahe requires an investment cost of Rp 505,015,298 or $\mathrm{Rp} 35,977,951$ per $\mathrm{kW}$, the proceeds from the sale of electrical energy produced by the 
MHP. Operational and maintenance costs are costs that must be prepared to carry out operational and maintenance activities. In this study, it is assumed that the operational and maintenance costs amount to $1 \%$ of the total project investment costs.

$$
\begin{aligned}
& O M=1 \% \times \operatorname{Rp} 505,015,298 \\
& O M=\operatorname{Rp} .5,050,153
\end{aligned}
$$

\subsection{Net Present Value}

Net Present Value is an assessment of the project value by analyzing the cash flow obtained by comparing the revenue and issuance each year with the discount factor. The discount factor can be found using the interest rate. In this study it is assumed that the interest rate is $10 \%$, so the discount factor is calculated in year 1. (Harto Jawadz, Prasetijo, and Purnomo 2019). In the first year the discount factor is 0.909 . To find out the cash flow (Cf) in year 1, it is necessary to find the difference between revenue (Ci) and expenditure (Co) which was previously multiplied by the discount factor that was previously sought.

$$
\begin{aligned}
& C_{f 1}=C_{i}-C_{o} \\
& C_{f 1}=(R p .94 .681 .023 x 0,909)-(\text { Rp. } 5.050 .153 \times 0,909) \\
& \mathrm{C}_{\mathrm{f} 1}=\text { Rp. } 86.065 .050
\end{aligned}
$$

The same calculation is carried out to find the discount factor in years 2 to 10 according to the planned age of the project. The results of the calculations that have been done are shown in the table below.

Tabel 5. The calculation of NPV

\begin{tabular}{ccrrr}
\hline \multicolumn{3}{c}{ NPV Calculation } & \multicolumn{3}{c}{ NPV with Discount Factors 10\% } \\
Years & Discount Factors & Cash in (Rp) & Cash out (Rp) & Cashflows (Rp) \\
\hline 0 & 1 & 0 & 505.015 .298 & 505.015 .298 \\
1 & 0,909 & 86.065 .050 & 4.590 .589 & 81.474 .461 \\
2 & 0,826 & 78.206 .525 & 4.171 .426 & 74.035 .099 \\
3 & 0,751 & 71.105 .449 & 3.792 .665 & 67.312 .784 \\
4 & 0,683 & 64.667 .139 & 3.449 .254 & 61.217 .884 \\
5 & 0,621 & 58.796 .916 & 3.136 .145 & 55.660 .771 \\
6 & 0,564 & 53.400 .097 & 2.848 .286 & 50.551 .811 \\
7 & 0,513 & 48.571 .365 & 2.590 .728 & 45.980 .637 \\
8 & 0,467 & 44.216 .038 & 2.358 .421 & 41.857 .616 \\
9 & 0,424 & 40.144 .754 & 2.141 .265 & 38.003 .489 \\
10 & 0,386 & 36.546 .875 & 1.949 .359 & 34.597 .516 \\
Total & - & 581.720 .208 & 536.043 .438 & 45.676 .769 \\
\hline
\end{tabular}

From the results of these calculations it is known that the NPV value obtained is Rp. $45,676,769$. This indicates that the NPV> 0 which means the project is feasible to continue.

\subsection{Benefit Cost Ratio}

Benefit cost ratio is the ratio between the revenue obtained from the sale of electrical energy with the total costs that must be incurred during the life of the project. In this study, the benefit cost ratio obtained is

$B C R=\frac{P V[\text { Benefits }]}{P V[\text { [ost }]}$ 
$B C R=\frac{R p \cdot 581 \cdot 720 \cdot 208}{R p \cdot 536 \cdot 043 \cdot 438}=1,0852$

Based on these calculations, the benefit cost ratio obtained is more than 1 ( $B C R>1)$, which is 1.0852 . This shows that this project is worth continuing.

\subsection{Payback Period}

The payback period shows the time it takes for the project to be able to return the investment value from the reduced revenue for operations and maintenance each year. In this study, the accumulated cash flow value was calculated to determine the year in which the accumulated cash flow value was positive.

Tabel 6. The Calculation of Net Cashflow PBP

\begin{tabular}{ccccc}
\hline Year & Cash in (Rp) & Cash Out (Rp) & Net Cash flow (Rp) & Cashflow (Rp) \\
\hline 0 & 0 & 505.015 .298 & 505.015 .298 & 0 \\
1 & 86.065 .050 & 509.605 .887 & 423.540 .837 & 81.474 .461 \\
2 & 164.271 .576 & 513.777 .314 & 349.505 .738 & 155.509 .560 \\
3 & 235.377 .024 & 517.569 .979 & 282.192 .955 & 222.822 .344 \\
4 & 300.044 .163 & 521.019 .233 & 220.975 .070 & 284.040 .228 \\
5 & 358.841 .079 & 524.155 .378 & 165.314 .300 & 339.700 .999 \\
6 & 412.241 .176 & 527.003 .664 & 114.762 .489 & 390.252 .810 \\
7 & 460.812 .541 & 529.594 .393 & 68.781 .852 & 436.233 .446 \\
8 & 505.028 .579 & 531.952 .814 & 26.924 .236 & 478.091 .063 \\
9 & 545.173 .333 & 534.094 .079 & 11.079 .253 & 516.094 .552 \\
10 & 581.720 .208 & 536.043 .438 & 45.676 .769 & 550.692 .068 \\
\hline
\end{tabular}

Based on the results of the calculations in table 10, it is known that the last year the net cash flow was negative occurred in the 3rd year as (n). In calculating the payback period, it is necessary to know the investment costs as (a), the value of accumulative cash flow for the 3rd year as (b), and the accumulative cash flow for the 4th year as (c). The results of the cash flow calculation are used to calculate the payback for the following period:

$P P=n+\frac{a-b}{b-c} \times 1$ year

$P P=8+\frac{R p .505 .015 .298-R p .11 .079 .253}{R p .516 .094 .552-R p .11 .079 .253} \times 1$ year

$P P=8,978$ year

Based on the calculation results, the payback period or the payback period for investment can occur for 8.978 years or 9 years.

\subsection{Internal Rate Return}

Internal rate of return is an indicator of the level of efficiency of an investment which shows how much the interest rate provided by the investment is compared to the interest rate from the bank. To be able to find the IRR value, it is necessary to look for a discount factor when the NPV is negative, which is greater than the interest rate on the NPV. In this study, an interest rate of $34 \%$ was used.

First year $-1=\frac{1}{(1+34 \%)^{1}}=0,746$ 
In the first year the discount factor is known to be 0.746 . To find out the cash flow in year 1 , it is necessary to find the difference between revenue and expenditure which was previously multiplied by the discount factor that was previously sought.

Cashflow year 1 = Receipt-Expenditure

Cash flow year $1=($ Rp. 94,681,023-0,746) $-($ Rp. 5,050,153 x 0.746 $)=$ Rp. 70,632,043

Table 7. Calculation of NPV with interest rate $34 \%$

\begin{tabular}{ccrrr}
\hline \multicolumn{2}{c}{ IRR Calculation } & \multicolumn{3}{c}{ NPV with Discount Factors 10\% } \\
Years & Discount Factors & Revenue (Rp) & Expenditure (Rp) & Cashflows (Rp) \\
\hline 0 & 1 & 0 & 505.015 .298 & 505.015 .298 \\
1 & 0,746 & 70.632 .043 & 3.767 .414 & 66.864 .629 \\
2 & 0,557 & 52.737 .330 & 2.812 .935 & 49.924 .395 \\
3 & 0,416 & 39.387 .306 & 2.100 .864 & 37.286 .442 \\
4 & 0,31 & 29.351 .117 & 1.565 .547 & 27.785 .570 \\
5 & 0,231 & 21.871 .316 & 1.166 .585 & 20.704 .731 \\
6 & 0,173 & 16.379 .817 & 873.676 & 15.506 .141 \\
7 & 0,129 & 12.213 .852 & 651.470 & 11.562 .382 \\
8 & 0,096 & 9.089 .378 & 484.815 & 8.604 .564 \\
9 & 0,072 & 6.817 .034 & 363.611 & 6.453 .423 \\
10 & 0,054 & 5.112 .775 & 272.708 & 4.840 .067 \\
Total & & 263.591 .969 & 519.074 .924 & 255.482 .955 \\
\hline
\end{tabular}

From the calculation results in the table, it is known that the NPV obtained with a discount factor of $34 \%$ is RP- $255,482,995$ with

The results are performed the following IRR calculations:

$$
\begin{aligned}
& I R R=10 \%+\frac{R p .45 .676 .769}{(R p .45 .676 .769-(-R p .255 .482 .955)} x(34-10) \% \\
& I R R=10 \%+0,0364 \times 24 \% \\
& I R R=10,0087 \%
\end{aligned}
$$

Based on the calculation, it is known that the IRR level in this project is $10.0087 \%$, which means that this project is feasible and profitable.

\section{Conclusion}

\section{Technical Feasibility}

Based on the results of this study, the following conclusions were obtained:

1. Coban Jahe water flow has a potential flow of water with a reliable discharge of $0.60567 \mathrm{~m} 3 / \mathrm{s}$ and an effective head of $3.4742 \mathrm{~m}$.

2. The hydropower potential can be utilized to plan the construction of an MHP with a capacity of $14.0368 \mathrm{~kW}$.

3. The turbine used is a Kaplan turbine from a low head and the generator used is $15 \mathrm{~kW}$.

\section{Economic Feasibility}

1. The investment cost required for the construction of MHP Plant is Rp. 505,015,298 or RP 35,977,951 per kW.

2. The planning of this MHP Plant project is feasible to be continued with a project life of 10 years with economic analysis such as NPV of Rp. 45,676,769. This shows that the NPV $>0$ means that the project is feasible to be continued. The Benefit Cost Ratio obtained is 1.0852 and is obtained more than 1 (BCR> 1). This shows that this project is worth continuing. Payback Period within 9 years. Based on the calculation results, and the IRR on this project is $10.0087 \%$, which means this project is feasible and profitable. 


\section{REFERENCES}

1. Chauhan A, Saini RP. A review on Integrated Renewable Energy System based power generation for stand-alone applications: Configurations, storage options, sizing methodologies and control. Renew Sustain Energy Rev. 2014 Oct;38:99-120.

2. Penche C. Guide on How to Develop a Small Hydropower Plant. Eur Small Hydropower Assoc. 2004;296.

3. Firmansyah I, Mahmudsyah S, Yuwono T. Studi Pembangunan Pembangkit Listrik Tenaga Mikro Hidro (PLTMH) Dompyong 50kW Di Desa Dompyong, Bendungan, Trenggalek Untuk Mewujudkan Desa Mandiri Energi (DME). Jur Tek Elektro FTI-ITS. 2008;1.

4. Harto Jawadz UR, Prasetijo H, Purnomo WH. Studi Potensi Pembangkit Listrik Tenaga Mikro Hidro (PLTMH) Di Aliran Sungai Desa Kejawar Banyumas. Din Rekayasa. 2019 Feb 1;15(1):11.

5. Marhendi T. Studi Potensi Pembangkit Listrik Tenaga Mikro Hidro Di Sungai Brukah (Kali Bening, Banjarnegara). Techno (Jurnal Fak Tek Univ Muhammadiyah Purwokerto). 2019 Apr 30;20(1):10.

6. Mantiri HE, Rumbayan M, Mangindaan GMC. Perencanaan Pembangkit Listrik Tenaga Listrik Minihidro Sungai Moayat Desa Kobo Kecil Kota Kotamobagu. J Tek Elektro dan Komput. 2018;7(3):227-38.

7. Prabowo Y, B S, Nazori N, Gata G. Studi Kelayakan Pembangkit Listrik Tenaga Mikrohidro (Pmlth) Pada Saluran Irigasi Gunung Bunder Pamijahan Bogor. J Ilm FIFO. 2018 Jun 10;10(1):41.

8. Patel SU, Pakale PN. Study on Power Generation By Using Cross Flow Water Turbine in Micro Hydro Power Plant. Int J Res Eng Technol. 2015;04(05):1-4.

9. Sallata MK, Nugroho HYSH, Wakka AK. THE UTILIZATION OF MICROHYDRO POWER TO ESTABLISH ENERGY SELF-SUFFICIENT VILLAGE. J Penelit Kehutan Wallacea. 2015 Apr 30;4(1):71

10. Saputra AT, Weking AI, Artawijaya IW. Eksperimental Pengaruh Variasi Sudut Ulir Pada Turbin Ulir (Archimedean Screw) Pusat Pembangkit Listrik Tenaga Mikro Hidro Dengan Head Rendah. Maj IIm Teknol Elektro [Internet]. 2019 May 6;18(1):83. Available from: https://ojs.unud.ac.id/index.php/JTE/article/view/45313

11. Dwiyanto V, Kusumastuti DI, Tugiono S. Analisis Pembangkit Listrik Tenaga Mikro Hidro (PLTMH) Studi Kasus: Sungai Air Anak (Hulu Sungai Way Besai). J Rekayasa Sipil dan Desain. 2016;4(3).

12. Sukamta S. Studi Analisis Pembangkit Listrik Tenaga Mikrohidro di Kedung Sipingit Desa Kayupuring Kecamatan Petungkriyono Kabupaten Pekalongan. Edu Elektr J. 2018;7(1).

13. Murni SS, Suryanto A. Analisis Efisiensi Daya Pembangkit Listrik Tenaga Mikrohidro Menggunakan HOMER (Studi Kasus PLTMH Parakandowo Kabupaten Pekalongan). J List Instrumentasi, dan Elektron Terap. 2020;1(2).

14. Nasir BA. Design of Micro-Hydro-Electric Power Station. Int J Eng Adv Technol. 2013;2(5):39-47.

15. Firmansyah R, Utomo T, Purnomo H. Perancangan Pembangkit Listrik Tenaga Mikrohidro Gunung Sawur Unit 3 Lumajang. J Mhs TEUB. 2014;2(7).

16. Harto Jawadz UR, Prasetijo H, Purnomo WH. Studi Potensi Pembangkit Listrik Tenaga Mikro Hidro (PLTMH) Di Aliran Sungai Desa Kejawar Banyumas. Din Rekayasa. 2019; 